\title{
Fucosylated Umbilical Cord Blood Regulatory T Cells
}

National Cancer Institute

\section{Source}

National Cancer Institute. Fucosylated Umbilical Cord Blood Regulatory T Cells. NCI

Thesaurus. Code C121830.

Fucosylated, human umbilical cord blood (UCB)-derived regulatory T-cells (T regs), with potential immunomodulating activity. Ex vivo, T regs are isolated from cord blood, expanded, and fucosylated. Upon infusion, the fucosylated UCB T regs modulate immune responses and induce tolerance to allogeneic transplants, such as hematopoietic stem cell transplants (HSCTs). This suppresses graft-versus-host disease (GVHD).

Fucosylation improves the activity of Tregs and reduces the amount of Tregs that need to be expanded and infused. 